\title{
A novel approach in the treatment of neuroendocrine gastrointestinal tumours. Targeting the epidermal growth factor receptor by gefitinib (ZDI839)
}

\author{
M Höpfner ${ }^{1,2}$, AP Sutter ${ }^{1,2}$, B Gerst', M Zeitz' and H Scherübl',1 \\ 'Medical Clinic I, Gastroenterology/Infectious Diseases/Rheumatology, University Hospital Benjamin Franklin, Free University of Berlin, Hindenburgdamm \\ 30, 12200 Berlin, Germany
}

Therapeutic options to inhibit the growth and spread of neuroendocrine (NE) gastrointestinal tumours are still limited. Since gefitinib (4-(3-chloro-4-fluoroanilino)-7-methoxy-6-(3-morpholinopropoxy)quinazoline), an inhibitor of epidermal growth factor receptorsensitive tyrosine kinase (EGFR-TK), had been shown to suppress potently the growth of various non-NE tumour entities, we studied the antineoplastic potency of gefitinib in NE gastrointestinal tumour cells. In human insulinoma (CM) cells, in human pancreatic carcinoid (BON) cells and in NE tumour cells of the gut (STC-I), gefitinib induced a time- and dose-dependent growth inhibition by almost $100 \%$. The antiproliferative potency of gefitinib correlated with the proliferation rate of the tumour cells. So the IC 50 value of gefitinib was $4.7 \pm 0.6 \mu \mathrm{M}$ in the fast-growing CM cells, still $16.8 \pm 0.4 \mu \mathrm{M}$ in the moderate-growing BON cells, and up to $31.5 \pm 2.5 \mu \mathrm{M}$ in the slow-growing STC-I cells. Similarly, the induction of apoptosis and cell-cycle arrest by gefitinib differed according to growth characteristics: fast-growing CM cells displayed a strong G0/GI arrest in response to gefitinib, while no significant cell-cycle alterations were seen in the slow-growing STC-I. Vice versa, the proapoptotic effects of gefitinib, as determined by caspase-3 activation and DNA fragmentation, were most pronounced in the slow-growing STC-I cells. Using cDNA microarrays, we found extensive changes in the expression of genes involved in the regulation of apoptosis and cell cycle after incubation with gefitinib. Among them, an upregulation of the growth arrest and DNA damage-inducible gene GADDI53 was observed. Phosphorylation of ERKI/2, which inhibits GADDI53 expression, was reduced in a time-dependent manner. However, no gefitinib-induced activation of the GADD I53-inducing P38 mitogen-activated protein kinase was detected. Our data demonstrate that the inhibition of EGFR-TK by gefitinib induces growth inhibition, apoptosis and cell-cycle arrest in NE gastrointestinal tumour cells. Thus, EGFR-TK inhibition appears to be a promising novel approach for the treatment of NE tumour disease.

British Journal of Cancer (2003) 89, I766- |775. doi:I0.1038/sj.bjc.660I346 www.bjcancer.com

(c) 2003 Cancer Research UK

Keywords: NE tumours; apoptosis; cell-cycle; EGFR; TK

Gastrointestinal neuroendocrine (NE) tumours represent a rare and rather heterogeneous tumour entity. Almost half of the metastatic NE gastrointestinal tumours release excessive amounts of biogenic amines and/or neuropeptides, thereby causing a characteristic hypersecretion syndrome. The often bizarre clinical symptoms are generally well controlled by somatostatin analogues or interferon- $\alpha$ (Faiss et al, 1996; Öberg, 2001). Therapeutic options to inhibit growth and further spread of metastatic NE tumours are yet very limited. Conventional chemotherapy is indicated in patients with anaplastic and fast-growing NE tumours, but provides no survival benefit for patients with slow disease progression. In the light of the particular biology of NE tumour disease, innovative treatment strategies should be developed that are both effective and well tolerated.

Recently, evidence has been accumulated indicating that the epidermal growth factor receptor (EGFR) is a promising target for

\section{*Correspondence: Dr H Scherübl;}

E-mail: hans.scheruebl@medizin.fu-berlin.de

${ }^{2}$ Both authors contributed equally to this work.

Received 9 June 2003; revised I September 2003; accepted 3 September 2003 novel cancer therapy. A great variety of tumours show abnormal, enhanced and/or constitutive expression of EGFR. Moreover, EGFR (over-) expression has been correlated with disease stage, reduced survival, development of tumour metastases and tumour differentiation in various cancers (Baselga, 2002; Di Lorenzo et al, 2002; Peghini et al, 2002). Several reports indicate that EGFR are expressed frequently in NE tumours in general (Wang et al, 1997; Ezzat, 2001), and in gastrointestinal NE tumours in particular (Nilsson et al, 1993, 1995; Öberg, 1994; Shimizu et al, 2000; Peghini et al, 2002). In addition, EGFR contributes to the growth characteristics of NE tumours (Nilsson et al, 1995; Wulbrand et al, 1998; Peghini et al, 2002). Hence, EGFR is an attractive target for innovative treatment strategies in gastrointestinal NE tumour disease.

The EGFR is part of a subfamily of four closely related receptors: EGFR (ErbB-1), HER-2/neu (ErbB-2), HER-3 (ErbB-3) and HER-4 (ErbB-4). Upon ligand binding EGFR becomes activated by dimerisation. The receptor activation leads to the subsequent activation of EGFR tyrosine kinase (TK) enzymatic activity, which plays a central role in receptor-mediated signal transduction, cell mitogenesis and cell transformation (Baselga, 2002). Inhibiting EGFR and their specific TK activity is regarded as a very promising 
approach for innovative therapeutic strategies in cancer treatment (Arteaga, 2002)

Gefitinib (4-(3-chloro-4-fluoroanilino)-7-methoxy-6-(3-morpholinopropoxy)quinazoline (ZD1839)), a specific EGFR-TK inhibitor, is currently in clinical testing for various tumour entities (Baselga et al, 2002; Herbst, 2002). Gefitinib is a low molecular weight (MW: 447), synthetic anilinoquinazoline. The orally available and reversibly acting drug is highly specific for EGFRTK, exhibiting almost no activity against other TKs and several serine/threonine kinases (Woodburn et al, 1998; Ciardiello and Tortora, 2001). Antineoplastic properties of gefitinib have been demonstrated in a wide range of human cancers, including prostate, breast, ovarian, colon, epidermoid and lung cancer cells (Ciardiello et al, 2000; Cullinane et al, 2000; Sirotnak et al, 2000; Chan et al, 2001; Di Lorenzo et al, 2002; Sewell et al, 2002).

EGFR-TK inhibition has not yet been evaluated in the antineoplastic treatment of NE tumours. Hence, in the present study, we examined the antineoplastic potency of the selective EGFR-TK inhibitor gefitinib in a set of NE gastrointestinal tumour cell lines with different growth characteristics. We focused on gefitinib-induced growth inhibition, its induction of apoptosis and regulation of the cell-cycle in NE gastrointestinal tumour cells.

\section{MATERIAL AND METHODS}

\section{Cell lines}

Human pancreatic carcinoid BON cells (Ahnert-Hilger et al, 1996; Lemmer et al, 2002) were maintained in a 1:1 mixture of DMEM, and F12K medium containing 10\% FCS (Biochrom, Berlin, Germany) and 1\% L-glutamine. The human insulinoma cell line CM (Baroni et al, 1999), kindly provided by Professor P Pozzilli (University La Sapienza of Rome, Italy), was cultured in RPMI 1640 supplemented with 5\% FCS (Biochrom) and 1\% L-glutamine. The murine intestinal NE tumour cell line STC-1 (Höpfner et al, 2002), which was a gift from Dr D Hanahan (University of California, San Francisco, CA, USA), was maintained in DMEM supplemented with $15 \%$ horse serum (Biochrom), $2.5 \%$ FCS (Biochrom) and $1 \%$ L-glutamine. All cell lines were kept at $37^{\circ} \mathrm{C}$ in a humidified atmosphere $\left(5 \% \mathrm{CO}_{2}\right)$.

\section{Drugs}

Gefitinib was a kind gift from AstraZeneca, Great Britain. Nonradiolabelled meta-iodobenzylguanidine (MIBG) was kindly provided by Amersham Buchler (Braunschweig, Germany). Stock solutions were prepared in DMSO and stored at $-20^{\circ} \mathrm{C}$. The drugs were diluted in fresh media before each experiment. In all experiments, the final DMSO concentration was $<0.5 \%$. To evaluate the effects of gefitinib and/or meta-iodobenzylguanidine, cells were incubated with either control medium or a medium containing rising concentrations of the respective drug or drug combination. Media were changed daily to ensure constant drug concentrations in the incubation medium.

\section{Reverse transcriptase-polymerase chain reaction (RT - PCR)}

The total RNA was extracted from cultured cell lines with RNAClean, following the recommendation of the manufacturer (Hybaid, London, UK). Reverse transcription and PCR reactions were carried out as described elsewhere in detail (Glassmeier et al, 1998). To eliminate any possible contamination with genomic DNA, RNAs were treated with $1 \mathrm{U}$ DNAse I (Gibco, Karlsruhe, Germany) per $\mu \mathrm{g}$ RNA for $15 \mathrm{~min}$ at room temperature. The possible contamination with genomic DNA was excluded by control experiments omitting the reverse transcriptase. Purified RNA was reverse transcribed into cDNA using oligo-dT-primers and the SuperScript Preamplification-Kit (Gibco). PCR reactions were carried out in a total volume of $50 \mu \mathrm{l}$ containing $400 \mathrm{~nm}$ of each primer, $200 \mu \mathrm{M}$ of each dNTP (Pharmacia, Uppsala, Sweden), $50 \mathrm{~mm} \mathrm{KCl}, 1.5 \mathrm{~mm} \mathrm{MgCl}_{2}, 10 \mathrm{~mm}$ tris(hydroxymethyl)-aminomethane (Tris) and $1 \mathrm{U}$ Taq-Polymerase (Pharmacia). PCR was performed in a Peltier thermocycler (PTC-200, MJ Research, Watertown, MA, USA) with primers and conditions as indicated in Table 1.

\section{cDNA array}

For determination of gefitinib-induced differential gene expression, human CM insulinoma cells were treated with gefitinib $(10 \mu \mathrm{M})$ for $48 \mathrm{~h}$. Untreated cells served as controls. Isolation of the total RNA of treated and untreated cells was performed as described above. Polyadenylated (polyA ${ }^{+}$) mRNAs were enriched using magnetic Dynabeads, according to the instructions of the supplier (Dynal, Oslo, Norway). The quality of total and polyA ${ }^{+}$ RNA was controlled by agarose gel electrophoresis. Labelled firststrand cDNA probes were prepared from the polyA ${ }^{+}$RNAs of both gefitinib-treated and control samples. Each sample was hybridised to an individual membrane of identically spotted 205 apoptosis- and cell-cycle-related genes (Human Apoptosis Array; Clontech, Palo Alto, CA, USA). A complete list of the cDNAs and controls as well as their accession numbers is available on the web (http://atlasinfo.clontech.com/genelists/huApop.xls). After washing, according to the manufacturer's instructions, the membranes were exposed to an X-ray film for quantification. Alteration in the expression of a respective gene is given as fold increase/or decrease compared with the signal of the untreated control (Höpfner et al,

Table I Primer sequences and PCR conditions for the detection of mRNA expression of the indicated genes in NE gastrointestinal tumour cells

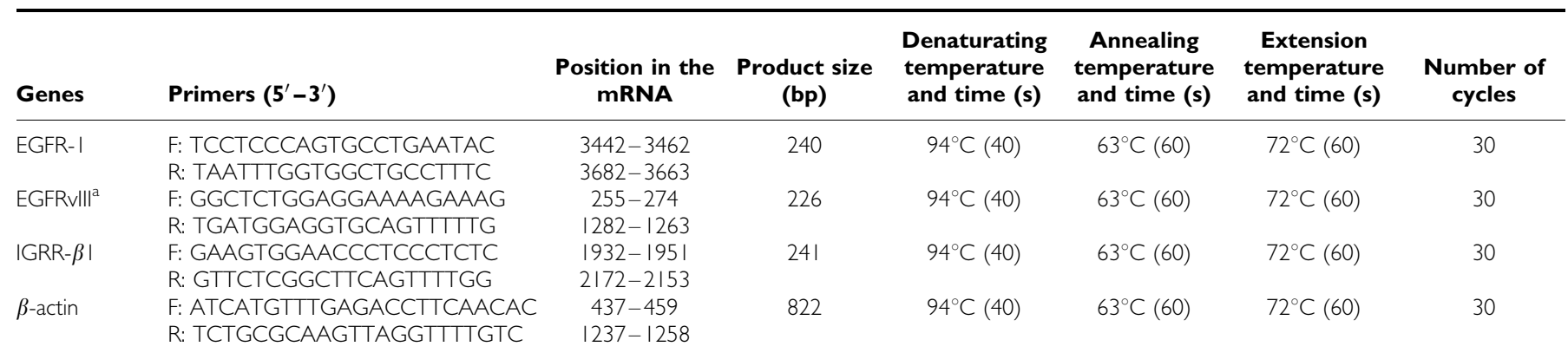

${ }^{a}$ EGFRvIll does not possess an mRNA-sequence distinct from the EGFR-I sequence, but Exons 2-7 are missing. Using the indicated primers, EGFRvIll is characterised by a product of $226 \mathrm{bp}$ size, while the wild-type receptor is recognised with a bp product of $1028 \mathrm{bp}$. All templates were initially denaturated for 5 min at $95^{\circ} \mathrm{C}$ and the amplification was extended at a final extension temperature of $72^{\circ} \mathrm{C}$ for $7 \mathrm{~min}$. 
2002). The hybridisation signals were photometrically evaluated using TINA software (Raytest Isotopenmessgeräte, Straubenhardt, Germany). For determination of up- and downregulation, the mean optical density $/ \mathrm{mm}^{2}\left(\mathrm{OD} / \mathrm{mm}^{2}\right)$ of each gene was identified and normalised to housekeeping gene expression (ubiquitin, GAPDH, tubulin $\alpha 1$ subunit, HLAC, cytoplasmic $\beta$-actin, 60S ribosomal protein $\mathrm{L} 13 \mathrm{~A}, 40 \mathrm{~S}$ ribosomal protein $\mathrm{S} 9$ ). Then the ratio of gene expression in treated $v s$ untreated cells was calculated. The cutoff for upregulation was set at a 1.5-fold increase of the OD/ $\mathrm{mm}^{2}$ ratio of genes in the treated samples, whereas downregulation was determined as the 0.67 -fold $\mathrm{OD} / \mathrm{mm}^{2}$ (reciprocal value of 1.5 fold increase) expression of genes in the treated samples.

\section{Western blotting}

Whole-cell extracts were prepared by harvesting and lysing cells with lysis buffer (sodium dodecyl sulphate (SDS) $0.1 \%$, sodium deoxycholic acid $0.5 \%$, Nonidet P-40 1\%, phenylmethylsulphonyl fluoride (PMSF) $0.1 \mathrm{~mm}$, aprotinin $1 \mu \mathrm{g} \mathrm{ml}^{-1}$, pepstatin A $\left.1 \mu \mathrm{g} \mathrm{ml}^{-1}\right)$. The protein content of the lysate was determined using the BCA protein assay kit (Pierce, Rockford, IL, USA). The cell lysate was mixed with gel-loading buffer (Tris- $\mathrm{HCl} 62.5 \mathrm{~mm}$, glycerol $10 \%$, SDS $1 \%, \beta$-mercaptoethanol $2.5 \%)$. After boiling for $5 \mathrm{~min}$, the lysates were subjected to SDS/polyacrylamide gel electrophoresis (30 $\mu \mathrm{g}$ of protein per lane; gel: polyacrylamide $10 \%$, SDS $0.1 \%$, Tris- $\mathrm{HCl} 25 \mathrm{~mm}$; running buffer: Tris $25 \mathrm{~mm}$, glycine $50 \mathrm{~mm}, 0.1 \%$ SDS). After electrophoresis, gels were equilibrated with transfer buffer (Tris- $\mathrm{HCl} 25 \mathrm{~mm}$, glycine $50 \mathrm{~mm}, 20 \%$ methanol). Proteins were transferred onto nitrocellulose membranes by electroblotting (BioRad, Munich, Germany). Blots were blocked in $1.5 \%$ bovine serum albumine (BSA), and then incubated at $4{ }^{\circ} \mathrm{C}$ overnight with the total p38 mitogen-activated protein kinase (MAPK) and phospho-p38 MAPK or the total extracellular signal-regulated kinase $1 / 2$ (ERK1/2) and phosphoERK1/2 antibodies, respectively $(1: 500$, Santa Cruz Biotechnology, CA, USA). After washing with phosphate-buffered $\mathrm{NaCl}$ solution (PBS) containing $0.1 \%$ Tween and incubation with horseradish peroxidase-coupled secondary antibody $(1: 10000$, Amersham, Uppsala, Sweden) at room temperature for $1 \mathrm{~h}$, the blot was washed extensively and developed using enhanced chemiluminescent detection (Amersham, Uppsala, Sweden). Blots were exposed to Hyperfilm ECL film (Amersham, Uppsala, Sweden) for 1-5 min.

\section{Immunofluorescence labelling}

Cells were trypsinised, washed twice with PBS and immunostained, as described previously (Sutter et al, 2002). Then samples were fixed and permeabilised using the Fix \& Perm cell permeabilisation kit (Caltag, Laboratories, Hamburg, Germany). Cells were incubated for $1 \mathrm{~h}$ at room temperature with the primary rabbit polyclonal IGF- $\beta 1$ receptor antibody $\left(5 \mu \mathrm{g} \mathrm{ml}^{-1}\right.$, \# sc-713, Santa Cruz) or with rabbit polyclonal EGF receptor antibody $\left(5 \mu \mathrm{g} \mathrm{ml}^{-1}\right.$, \# sc-03, Santa Cruz), both mapping at the respective C-terminus of the protein. Negative controls were performed by omitting the primary antibody. Cells were washed twice with PBS and then incubated with secondary FITC-labelled polyclonal anti-rabbit Ig antibody ( $5 \mu \mathrm{g} \mathrm{ml}^{-1}, \mathrm{BD}$ Pharmingen, Heidelberg, Germany) for $1 \mathrm{~h}$ at room temperature. Fluorescence was detected by flow cytometry on a FACSCalibur (Becton Dickinson, Heidelberg, Germany) and analysed using CellQuest software.

\section{Measurement of growth inhibition}

Changes in the cell number of BON, CM and STC-1 cells were determined by crystal violet staining after $96 \mathrm{~h}$ of incubation with rising concentrations of gefitinib $(0-50 \mu \mathrm{M})$. Measurements were performed as described (Höpfner et al, 2001). Cells were washed with PBS and fixed with $1 \%$ glutaraldehyde. After another washing step, cells were stained with $0.1 \%$ crystal violet. The unbound dye was removed by washing. Crystal violet that had absorbed onto the cells was solubilised with $0.2 \%$ Triton X-100. Then light extinction was analysed at $570 \mathrm{~nm}$ using an ELISA reader.

\section{Caspase- 3 activity assay}

Preparation of cell lysates and determination of caspase-3 activity was performed as described previously (Maaser et al, 2002). The activity of caspase-3 was calculated from the cleavage of the fluorogenic substrate DEVD-AMC (Calbiochem-Novabiochem, Bad Soden, Germany). Cell lysates were incubated with substrate solution (caspase-3 substrate AC-DEVD-AMC $20 \mu \mathrm{g} \mathrm{ml}^{-1}$, HEPES $20 \mathrm{~mm}$, glycerol $10 \%$, DTT $2 \mathrm{~mm}, \mathrm{pH} 7.5$ ) for $1 \mathrm{~h}$ at $37^{\circ} \mathrm{C}$, and the cleavage of DEVD-AMC was measured fluorometrically with a VersaFluor fluorometer (excitation: $360 \mathrm{~nm}$ emission: $460 \mathrm{~nm}$ ) from Biorad, Munich, Germany.

\section{DNA fragmentation}

DNA fragmentation was determined by performing Cell Death Detection ELISA (Roche) as described previously (Höpfner et al, 2003). Briefly, after $48 \mathrm{~h}$ of incubation, cells were lysed with incubation buffer. The cytoplasmic fractions were diluted to contain $2.5 \times 10^{3}$ cell equivalents per $\mathrm{ml}$, and the presence of mono- and oligonucleosomes was assayed using antibodies directed against DNA and histones. DNA fragments were detected by a peroxidase system with colour development read at $405 \mathrm{~nm}$.

\section{Cell-cycle analysis}

Cell-cycle analysis was performed by the method of Vindelov and Christensen, as described previously (Maaser et al, 2001). Cells were trypsinised, washed and the nuclei were isolated using the CycleTest PLUS DNA Reagent Kit (Becton Dickinson, Heidelberg, Germany). DNA was stained with propidium iodide according to the manufacturers' instructions. The DNA content of the nuclei was detected by flow cytometry and analysed using CellFit software (Becton Dickinson).

\section{Statistical analysis}

The antineoplastic effects of the various substances and vehicles were compared by the unpaired, two-tailed Mann - Whitney $U$-test. The unpaired Student's $t$-test was used for cell-cycle analysis. $P$ values were considered to be significant at $<0.05$. If not stated otherwise, all functional experiments were performed in quadruplicate.

\section{RESULTS}

\section{Expression of EGFR and IGFR in NE gastrointestinal tumour cells}

The mRNA expression of EGF receptors (EGFR) and the insulinlike growth factor receptor $\beta-1$ (IGFR- $\beta 1$ ) was investigated in human BON and in human CM cells. The mRNAs specific for EGFR and IGFR $\beta$ - 1 were detected in both the cell lines (Figure 1A, B). To evaluate protein expression of both EGFR and IGFR $\beta-1$, cells were stained with specific antibodies and analysed by flow cytometry. Protein expression of EGFR and IGFR- $\beta 1$ was detected in both the cell lines (Figure 1C, D). By contrast, no expression of the EGFR mutation, EGFRvIII, often observed in non-NE cancer types, was detected in the human NE tumour models used (Figure 1A, B). Labelling murine STC-1 cells with specific antibodies for EGFR and IGFR- $\beta 1$ also confirmed the expression of both growth factor receptors in this model of NE gut tumour cells (Figure 1D). 
A

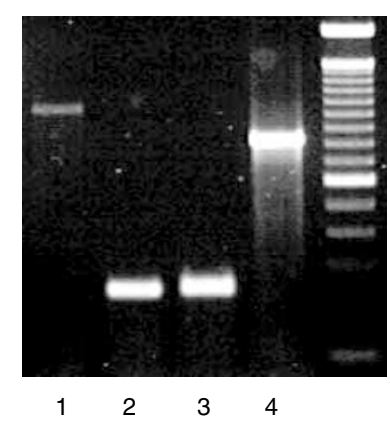

B

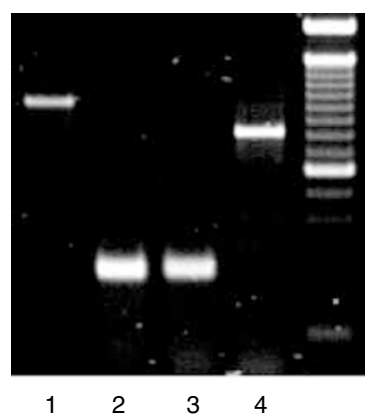

C

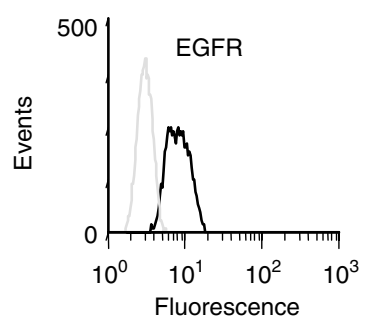

D

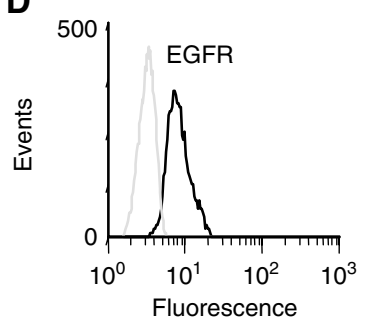

E

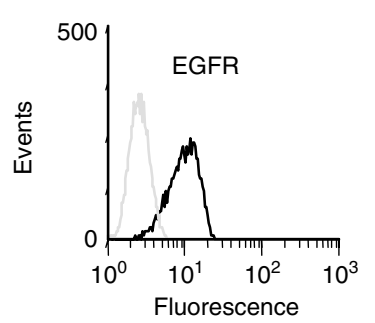

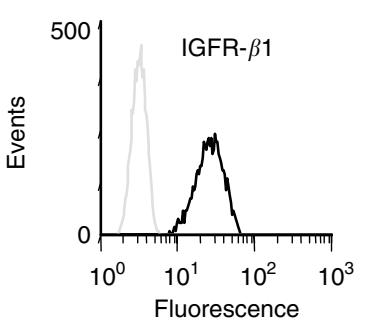
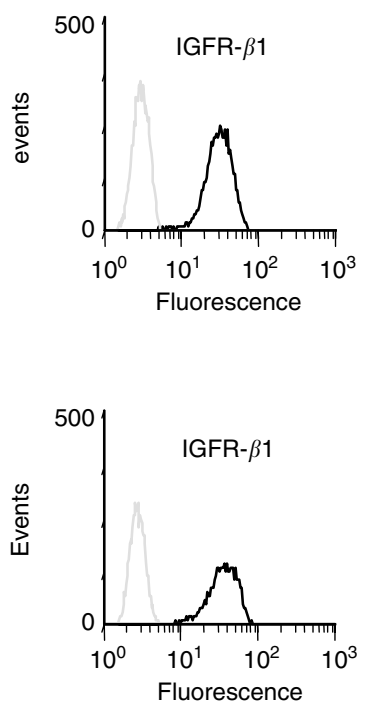

Figure I mRNA and protein expression of EGFR and IGFR in neuroendocrine tumour cells. (A, B) mRNA expression of EGFRvIll (lane I), EGFR-I (lane 2) and IGFR $\beta$ - I (lane 3) was evaluated in CM (A) and BON tumour cells (B). $\beta$-Actin was used as positive control (lane 4 in $\mathbf{A}$ and $\mathbf{B}), 100 \mathrm{bp}$ DNA ladder. (C-E) Flow cytometric analysis of the expression of EGFR and IGFR $\beta$-I proteins in CM cells $(\mathbf{C})$, BON cells (D) and STC-I cells $(\mathbf{E})$. Black lines: cells stained with specific polyclonal antibodies against either EGFR or IGFR $\beta$-I; grey lines: negative controls.

\section{Growth-inhibitory effects of gefitinib}

Changes in the cell number caused by EGFR-TK inhibition were studied by performing crystal violet assays. Gefitinib $(0-50 \mu \mathrm{M})$ time- and dose-dependently inhibited the growth of all cell lines investigated (Figure $2 \mathrm{~A}-\mathrm{C}$ ). After $96 \mathrm{~h}$ of incubation, a decrease of almost $100 \%$ was observed. However, the $\mathrm{IC}_{50}$ values of gefitinib, determined after $48 \mathrm{~h}$, differed between the three cell lines. While in fast-growing CM cells (doubling time: $21 \pm 1 \mathrm{~h}$ ) the $\mathrm{IC}_{50}$ value of gefitinib amounted to $4.7 \pm 0.6 \mu \mathrm{M}$, it was $16.8 \pm 0.4 \mu \mathrm{M}$ in the

A

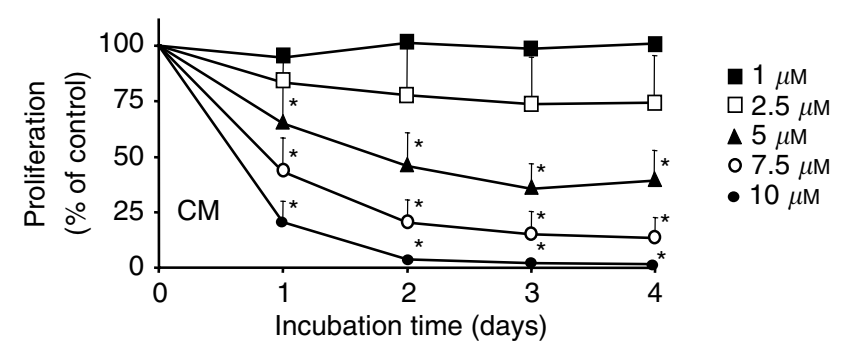

B

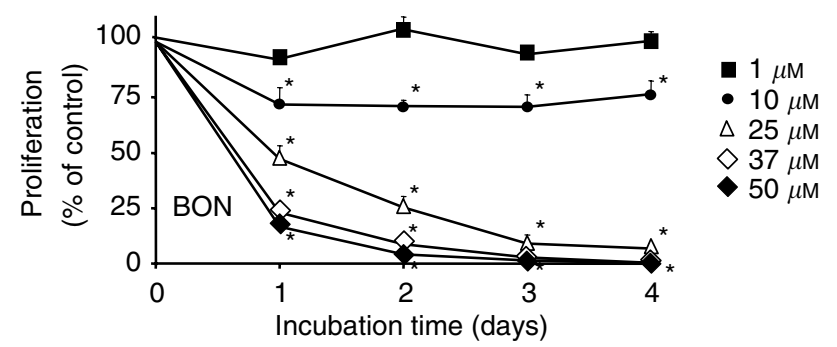

C

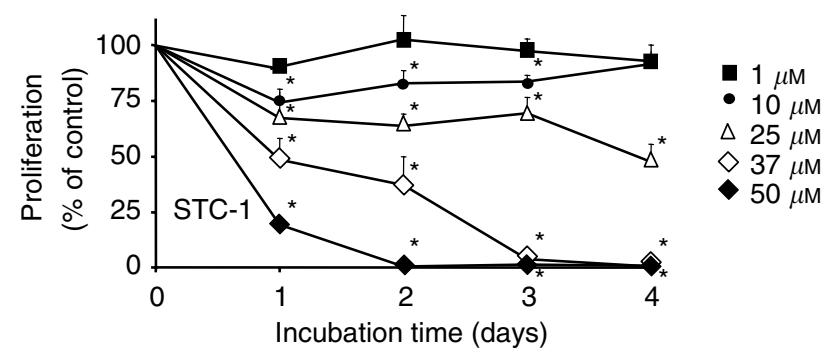

D

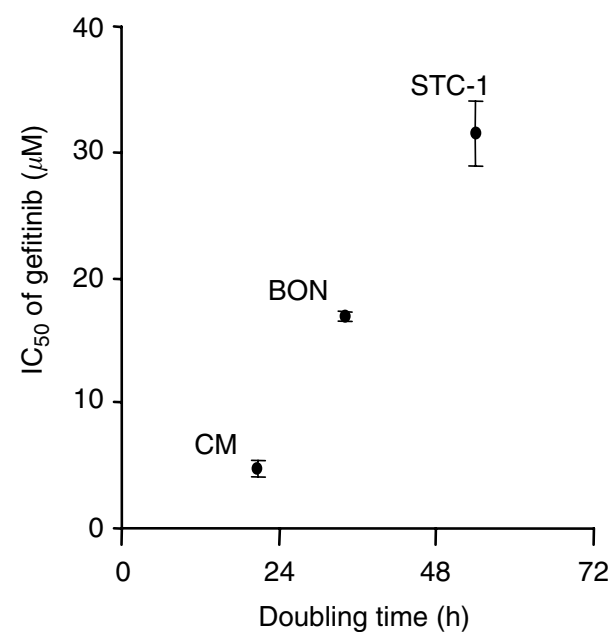

Figure 2 Gefitinib-induced growth inhibition. Gefitinib caused a timeand dose-dependent growth inhibition as measured by crystal violet staining. The $I C_{50}$ value was $4.7 \pm 0.6 \mu \mathrm{M}$ in fast-growing CM cells $(\mathbf{A})$, $16.8 \pm 0.4 \mu \mathrm{M}$ in moderate-growing BON cells $(\mathbf{B})$, and $31.5 \pm 2.5 \mu \mathrm{M}$ in slow-growing STC-I cells (C). (D) Correlation between the doubling time of NE gastrointestinal tumour cells and their sensitivity to gefitinib treatment. Data are given as the percentage of untreated controls (means \pm s.e.m. of four to five independent experiments). * Statistical significance $(P<0.05)$.

moderate-growing BON cells (doubling time: $34 \pm 4 \mathrm{~h}$ ), but as high as $31.5 \pm 2.5 \mu \mathrm{M}$ in the slow-growing STC-1 cells (doubling time: $54 \pm 6 \mathrm{~h}$ ) (Figure 2D). 
Recently, we showed that nonradiolabelled MIBG specifically inhibited the growth of norepinephrine transporter (NET)-positive $\mathrm{NE}$ gastrointestinal tumour cells with an $\mathrm{IC}_{50}$ value of $7.8 \mu \mathrm{M}$ (Höpfner et al, 2002). Thus, it was intriguing to evaluate the possible synergistic antiproliferative effects of the combination of gefitinib with MIBG. Incubating NET-positive STC-1 cells for 3 days with combinations of sub- $\mathrm{IC}_{50}$ concentrations of $\mathrm{MIBG}$ $(5 \mu \mathrm{M})$ and gefitinib $(10 \mu \mathrm{M})$ resulted in an overadditive growth-inhibitory effect. While each drug alone decreased the growth of STC-1 cells by either $23 \%$ (10 $\mu \mathrm{M}$ gefitinib) or $28 \%$ ( $5 \mu \mathrm{M}$ MIBG), the combination of both drugs led to a synergistic antiproliferative effect of more than $90 \%$ growth inhibition (data not shown).

\section{Gefitinib and cell-cycle regulation}

To test whether cell-cycle-arresting effects contributed to the antiproliferative potency of gefitinib in NE gastrointestinal tumour cells, we performed flow cytometric cell-cycle analysis. Challenging $\mathrm{CM}$ and $\mathrm{BON}$ cells with rising concentrations of gefitinib $(0-10 \mu \mathrm{M}$ in $\mathrm{CM}$, and $0-50 \mu \mathrm{M}$ in $\mathrm{BON}$ cells) for $48 \mathrm{~h}$ dose-dependently arrested $\mathrm{CM}$ and $\mathrm{BON}$ cells in the G1/G0 phase of the cell cycle, thereby decreasing the proportion of cells in the $S$ phase and G2/M phase (Figure 3A, B). Interestingly, gefitinib did not affect the cell cycle of STC-1 cells, even at the highest concentration of $50 \mu \mathrm{M}$ (Figure 3C).

\section{Proapoptotic effects of gefitinib}

To check whether the induction of programmed cell death contributed to the antineoplastic effects of gefitinib, we investigated gefitinib-induced caspase- 3 activation and DNA fragmentation in CM, BON and STC-1 cells.

Caspase- 3 is a key enzyme in the apoptotic signalling pathway. In all the three cell lines, gefitinib induced a dose-dependent increase in caspase-3 activity (Figure 4). The extent of caspase-3 activation differed between the three cell lines. Interestingly, caspase- 3 activation was most pronounced in the slow-growing STC-1 cells $(746 \pm 122 \%$ increase), which on the other hand had not displayed cell-cycle alterations in response to gefitinib treatment. This suggests that the antiproliferative effect of gefitinib in STC-1 cells is mainly caused by an induction of apoptosis. On the other hand, fast-growing CM cells, which exhibited the most pronounced G0/G1-arrest upon gefitinib treatment, showed the lowest, albeit still distinctive, caspase-3 activation of the three NE cell lines studied.

The fragmentation of DNA into mono- and oligonucleosomes is a hallmark of apoptosis. Gefitinib dose-dependently induced DNA fragmentation in NE gastrointestinal tumour cells (Figure 5). After $48 \mathrm{~h}$ of incubation, an increase in DNA fragmentation of up to approx. $380 \%$ of the control values was observed. The results on DNA fragmentation confirm the notion that gefitinib potently induces apoptosis in NE gastrointestinal tumour cells. The extent of DNA fragmentation corresponded to the findings of caspase-3 activation in the respective cell line. Thus, strongest DNA fragmentation was seen in STC-1 cells, while CM cells showed less pronounced DNA fragmentation after incubation with gefitinib.

Since the antiproliferative effect of MIBG on NET-positive STC-1 cells was mainly caused by an induction of apoptosis (Höpfner et al, 2002), we wondered whether the overadditive antiproliferative effect of MIBG plus gefitinib was due to a synergistic induction of apoptosis. After $48 \mathrm{~h}$ of incubation, DNA fragmentation induced by either drug amounted to $116 \%$ (10 $\mu \mathrm{M}$ gefitinib) or $105 \%(1 \mu \mathrm{M}$ MIBG), respectively. Combined incubation of STC-1 cells with MIBG $(1 \mu \mathrm{M})$ and gefitinib $(10 \mu \mathrm{M})$ revealed an overadditive activation of DNA-fragmentation of $141 \%$.

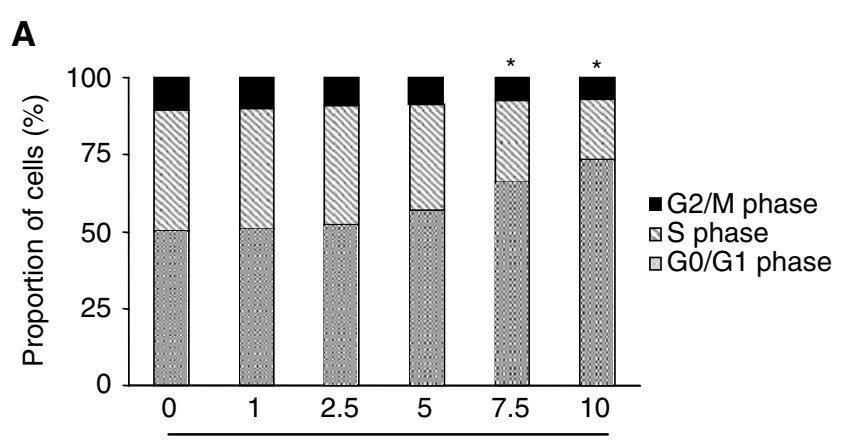

B Gefitinib $(\mu \mathrm{m})$
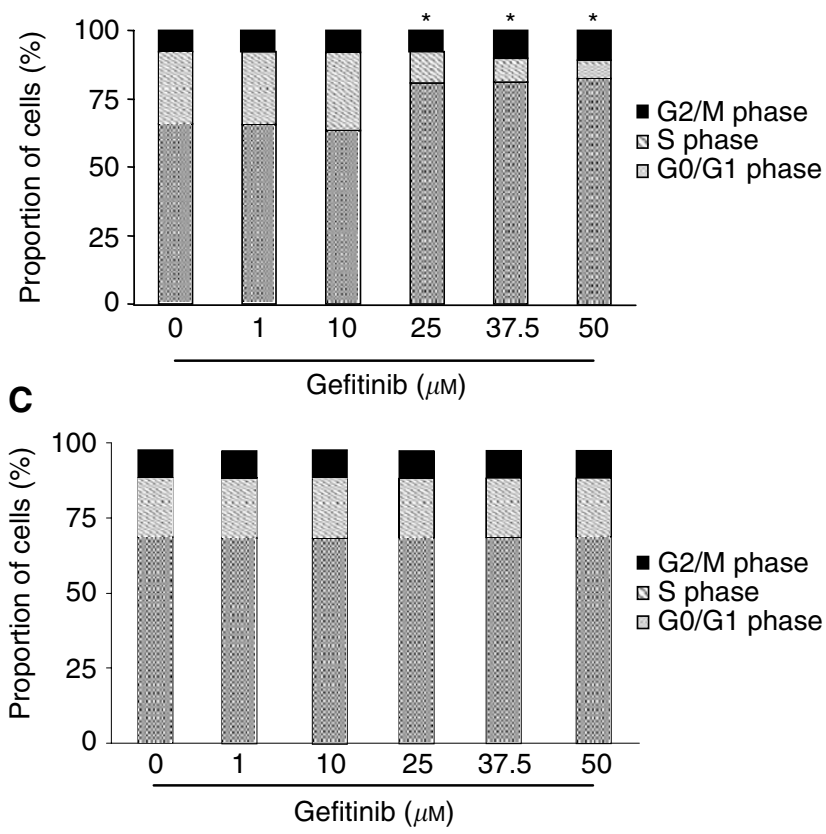

Figure 3 Induction of cell-cycle arrest by gefitinib. After $48 \mathrm{~h}$ of incubation with gefitinib, CM cells $(\mathbf{A})$ and $\mathrm{BON}$ cells (B) dosedependently accumulated in the GO/GI-phase of the cell cycle. Accordingly, the proportion of cells in the $\mathrm{S}$ and $\mathrm{G} 2 / \mathrm{M}$ phases decreased in either cell line. In contrast, no significant changes of cell-cycle phases were observed in STC-I cells (C). Means \pm s.e.m. of four independent experiments for each cell line are shown. The difference of the proportion of cells in a particular phase of the cell cycle vs control was significant for 7.5- $10 \mu \mathrm{M}$ gefitinib in CM cells and for 10-50 $\mu \mathrm{M}$ gefitinib in BON cells. * Statistical significance $(P<0.05)$

\section{Gefitinib-induced differential gene expression}

The present work demonstrates that gefitinib induces both apoptosis and cell-cycle arrest in NE gastrointestinal tumour cells. To study the involved cell-cycle and apoptosis genes at the transcriptional level, we performed cDNA microarray analysis of gefitinib-treated CM cells. For microarray experiments, we chose a concentration of $10 \mu \mathrm{M}$ gefitinib and a $48 \mathrm{~h}$ incubation time, which was shown to induce apoptosis and cell-cycle arrest in CM cells maximally.

We found 35 genes to be differentially expressed in CM cells upon gefitinib treatment. An asymmetric distribution of up- $v s$ downregulated genes became apparent (see Table 2). Among the genes known to be involved in the apoptosis signalling cascade, the expressions of caspase 4, PDCD 2, BCL-2-antagonist of cell death $(B A D)$ and the bcl-2 family protein harakiri were overexpressed in gefitinib-treated cells. GADD 153, which plays an important role both in apoptosis and G0/G1 arrest, was also upregulated. Among 


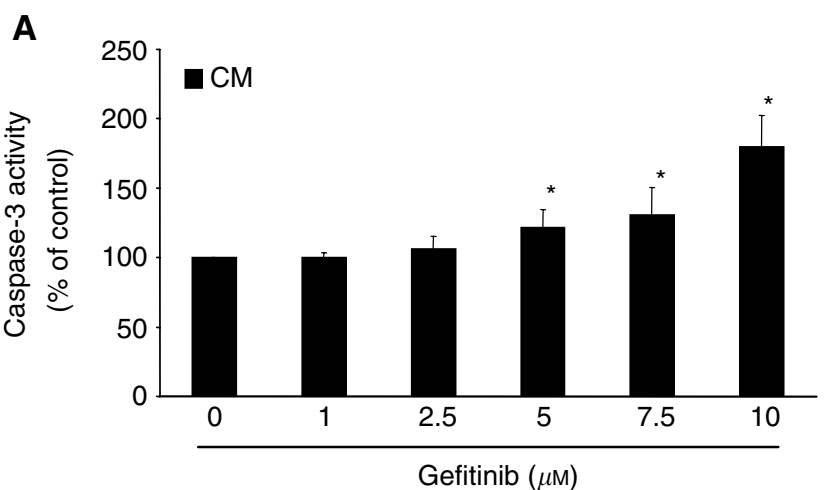

B

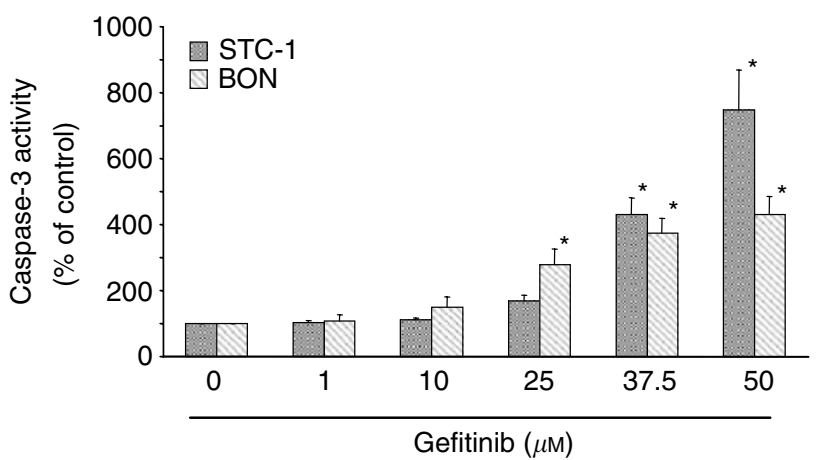

Figure 4 Gefitinib-induced caspase-3 activation. (A) In fast-growing CM cells, gefitinib $(I-10 \mu \mathrm{M})$ dose-dependently induced caspase-3 activation after $24 \mathrm{~h}$ of incubation. (B) Both the moderate-growing $\mathrm{BON}$ cells and the slow-growing STC-I cells showed increases in caspase-3 activation when challenged with I $-50 \mu \mathrm{M}$ gefitinib. Referring to the respective $I C_{50}$ values of gefitinib-induced growth inhibition, the apoptotic response in $\mathrm{BON}$ or STC-I cells was even more pronounced than in CM cells. Data are given as the percentage of untreated control (means \pm s.e.m. of four independent experiments for each cell line). * Statistical significance $(P<0.05)$

the genes being downregulated, the cell-cycle regulating kinases ERK1, CDC-like kinase 3, cyclin-dependent kinase 10 and the DNAreplication factor proliferating cell nuclear antigen (PCNA) were found.

\section{Gefitinib-mediated phosphorylation of ERK1/2 and p38 MAPK}

To shed light on the signalling pathways influenced by EGFR-TK inhibition, we investigated time-dependent alterations of the phosphorylation of ERK1/2 and p38 MAPK, which are members of the MAPK family known to be involved in EGFR signalling in non-NE tumours. Incubating $\mathrm{CM}$ cells for $0-48 \mathrm{~h}$ with $10 \mu \mathrm{M}$ gefitinib revealed a time-dependent decrease in the phosphorylation of mitogenic ERK1/2 (Figure 6A). In contrast, no significant alteration in the phosphorylation of the stress-activated p38 MAPK was observed (Figure 6B).

\section{DISCUSSION}

EGFR signalling impacts on many aspects of tumour biology. The activation of EGFR has been shown to enhance tumour growth, invasion and spreading, and to inhibit apoptosis (Moghal and Sternberg, 1999; Wells, 2000). In addition, the expression of EGFR in tumours has been correlated with disease progression, poor survival, poor response to therapy (Brabender et al, 2000) and the development of resistance to cytotoxic agents (Wosikowski et al,
A
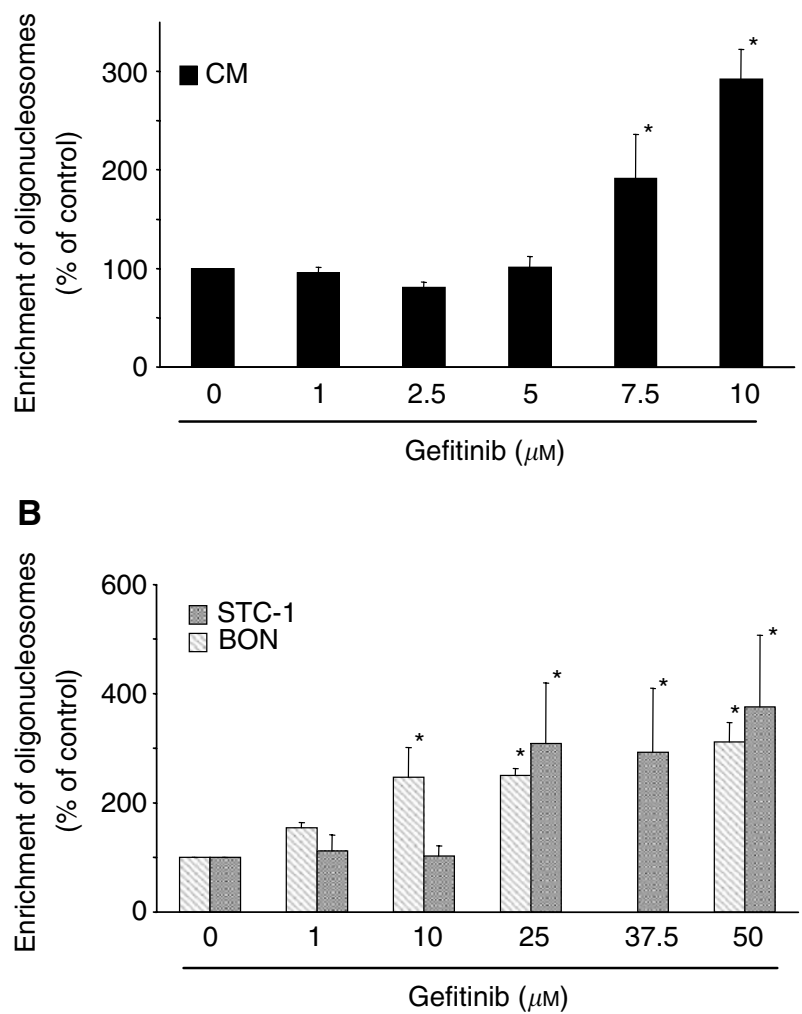

Figure 5 Gefitinib-induced DNA fragmentation. (A) Incubation of CM cells with $\mathrm{I}-10 \mu \mathrm{M}$ gefitinib for $48 \mathrm{~h}$ led to a dose-dependent formation of apoptosis-specific oligonucleosomes. (B) Dose-dependent increases in DNA fragmentation of BON and STC-I cells after $48 \mathrm{~h}$ incubation with gefitinib $(\mathrm{I}-50 \mu \mathrm{M})$. Data are given as the percentage of untreated control (means \pm s.e.m. of four independent experiments for each cell line). * Statistical significance $(P<0.05)$.

1997; Meyers et al, 1998). Thus, specific inhibition of EGFR and its intrinsic TK activity by different strategies (e.g. monoclonal antibodies, TK-inhibitors) has become a rationale for innovative cancer treatment (Ciardiello et al, 2000; Cullinane et al, 2000; Sirotnak et al, 2000; Overholser et al, 2000; Chan et al, 2001; Di Lorenzo et al, 2002; Sewell et al, 2002; Mendelsohn, 2003), especially since the EGF receptor system is not only involved in tumour growth but also plays a significant role in tumour invasion, angiogenesis and adhesion (Woodburn, 1999; Ritter and Arteaga, 2003).

In the present study, we provide evidence that NE gastrointestinal tumour cells express both EGFR and the EGFR transactivating IGFR- $\beta 1$ (Gilmore et al, 2002). Moreover, gefitinib, a specific EGFR-TK inhibitor, was found to inhibit potently the growth of NE gastrointestinal tumour cells by inducing cell-cycle arrest and/or apoptosis. The inhibition of EGFR-TK by gefitinib led to a time- and dose-dependent growth inhibition by almost $100 \%$. The effects were observed under foetal calf- and/or horse serum-containing conditions, that is, in the presence of growth factors like EGF, IGF and TGF- $\alpha$. Under these in vivo-like serum conditions, gefitinib was very potent, and thus qualifies as a promising novel drug to be tested clinically in metastatic NE gastrointestinal tumour disease.

The growth pattern of NE gastrointestinal tumours exhibits an astonishingly wide spectrum ranging from very slow- to moderategrowing types and finally to fast-growing, very aggressive types of tumours (Öberg, 1994). In view of this particular background, it 
Table 2 Transcripts differentially regulated in CM cells in response to gefitinib

\begin{tabular}{|c|c|c|c|}
\hline GenBank ID & Gene name & Function & Ratio \\
\hline U280|4 & caspase 4 & Caspase & 4.13 \\
\hline M63167 & rac protein kinase alpha & Death kinase & 3.27 \\
\hline S78085 & Programmed cell death 2 & Apoptosis-associated protein & 3.13 \\
\hline U66879 & BCL2-antagonist of cell death (BAD) & bcl-2 family protein & 2.81 \\
\hline Y00285 & Insulin-like growth factor 2 receptor & Growth factor receptor & 2.55 \\
\hline U91985 & DNA fragmentation factor alpha & DNA fragmentation protein & 2.52 \\
\hline M354I0 & Insulin-like growth-factor binding protein 2 & Growth factor-binding protein & 2.41 \\
\hline AF022385 & Programmed cell death 10 & Apoptosis-associated protein & 2.40 \\
\hline$\times 59798$ & Cyclin DI & Cyclin & 2.27 \\
\hline M81934 & Cell division cycle 25B & Cell cycle protein & 2.22 \\
\hline M323I 5 & Tumour necrosis factor receptor superfamily, member IB & Death receptor & 2.03 \\
\hline U66469 & Cell growth regulatory with ring finger domain & Cell cycle protein & 1.99 \\
\hline U76376 & harakiri, BCL2-interacting protein & bcl-2 family protein & 1.83 \\
\hline M25753 & Cyclin BI & Cyclin & 1.81 \\
\hline$\times 66363$ & PCTAIRE protein kinase । & cdc2-related protein kinase & 1.76 \\
\hline U25265 & Mitogen-activated protein kinase kinase 5 & Intracellular kinase network member & 1.76 \\
\hline S40706 & GADDI53 & Apoptosis-associated protein & 1.72 \\
\hline U78798 & TNF receptor-associated factor 6 & Death receptor-associated protein & 1.72 \\
\hline$\times 85134$ & Retinoblastoma-binding protein 5 & Cell cycle protein & $1.7 \mid$ \\
\hline L25080 & ras homologue gene family, member $\mathrm{A}$ & Oncogene & 1.70 \\
\hline MI3228 & v-myc myelocytomatosis viral-related oncogene & Oncogene & 1.68 \\
\hline M33294 & Tumour necrosis factor receptor superfamily, member IA & Death receptor & 1.67 \\
\hline MI5796 & Proliferating cell nuclear antigen & DNA replication & 0.65 \\
\hline D21090 & RAD23 homologue B & DNA damage signalling protein & 0.65 \\
\hline S72008 & Cell division cycle 10 & Cell cycle protein & 0.63 \\
\hline U39657 & Mitogen-activated protein kinase kinase 6 & Intracellular kinase network member & 0.63 \\
\hline$\times 66362$ & PCTAIRE protein kinase 3 & cdc2-related protein kinase & 0.61 \\
\hline$\cup|179|$ & Cyclin $\mathrm{H}$ & Cyclin & 0.58 \\
\hline$\times 60188$ & Extracellular signal-regulated kinase I (ERKI) & Cell cycle-regulating kinase & 0.55 \\
\hline L05624 & Mitogen-activated protein kinase kinase I & Intracellular kinase network member & 0.55 \\
\hline U75285 & Survivin & Apoptosis-associated protein & 0.54 \\
\hline$\times 79389$ & Glutathione S-transferase theta I & Xenobiotic transporter & 0.54 \\
\hline U78876 & Mitogen-activated protein kinase kinase kinase 3 & Intracellular kinase network member & 0.50 \\
\hline$\cup 21092$ & TNF receptor-associated factor 3 & Death receptor-associated protein & 0.47 \\
\hline L074|4 & Tumour necrosis factor superfamily, member 5 & Death receptor ligand & 0.42 \\
\hline M73812 & Cyclin EI & Cyclin & 0.26 \\
\hline
\end{tabular}
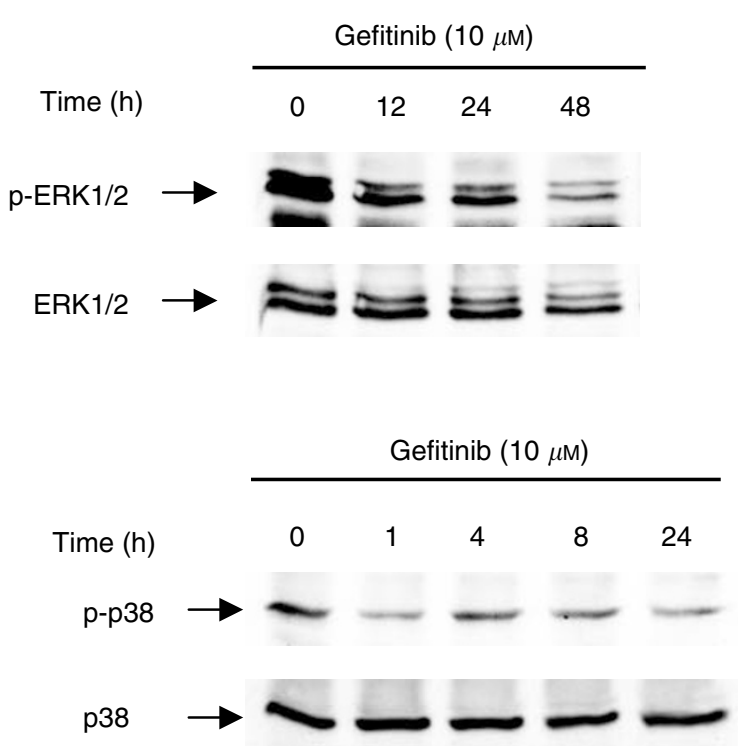

Figure 6 Effect of gefitinib on MAP kinase activity in CM cells. CM cells were treated with $10 \mu \mathrm{M}$ gefitinib for $0-48 \mathrm{~h}$. At the indicated time points, the amount of phosphorylation of ERKI/2 and p38MAP kinases was analysed by Western blotting. (A) Gefitinib induced a time-dependent decrease in phosphorylated ERKI/2. (B) By contrast, no change in p38 MAPK phosphorylation was observed upon treatment with gefitinib. was important to check whether gefitinib was similarly capable of inhibiting the proliferation of NE tumours with different growth characteristics and to study the involved signalling pathways. Therefore, we chose three models of NE gastrointestinal tumour disease, each characterised by a different growth pattern and different origin: first, human insulinoma CM cells, which have a doubling time of $21 \mathrm{~h}$ and represent 'fast-growing' NE tumour cells. Second, human pancreatic carcinoid BON cells with a doubling time of $34 \mathrm{~h}$, which represent 'moderate-growing' NE tumour cells. Third, 'slow-growing' NE tumour cells of the gut (STC-1 cells) with a doubling time of $54 \mathrm{~h}$. Each cell line was cultured under its optimal growth conditions, which resulted in different serum concentrations among the three cell lines. Nevertheless, the different serum concentrations were not responsible for the different antineoplastic efficacies of gefitinib observed in the three cell lines (data not shown). Although gefitinib effectively inhibited tumour growth in each model, differences concerning dose-response relationships and involved signalling pathways became apparent. In fast-growing $\mathrm{CM}$ cells that displayed the highest sensitivity to gefitinib ( $\mathrm{IC}_{50}$ of $\left.4.7 \pm 0.6 \mu \mathrm{M}\right)$, the antineoplastic effect was based on both a moderate induction of apoptosis and a strong G1/G0 phase arrest of the cell-cycle. In moderate-growing BON cells also an induction of apoptosis as well as an arrest in the G1/G0 phase of the cell-cycle were observed. However, the concentrations needed to induce the antineoplastic effects were significantly higher $\left(\mathrm{IC}_{50}\right.$ of $\left.6.8 \pm 0.4 \mu \mathrm{M}\right)$, and the apoptotic response was more pronounced than in CM cells. On the other hand, in slow-growing STC-1 cells displaying the lowest 
sensitivity to gefitinib $\left(\mathrm{IC}_{50} 31.5 \pm 2.5 \mu \mathrm{M}\right)$, the antineoplastic effect was based on a strong induction of apoptosis, while no significant cell-cycle alterations were observed.

The shift from a more cell-cycle arrest related action in fastgrowing NE tumour cells to an (almost) exclusively apoptosisrelated effect in slow-growing NE tumour cells may be important to be taken into account when considering novel combination therapies. In this respect, we were interested in the antiproliferative synergism between gefitinib and the norepinephrine derivative MIBG. Nonradiolabelled MIBG has recently been suggested as an innovative drug for the treatment of NE gastrointestinal tumours expressing plasma membraneous norepinephrine transporters (NET) (Taal et al, 1996; Höpfner et al, 2002). Since the coapplication of MIBG and gefitinib resulted in an overadditive, synergistic antiproliferative action in STC-1 cells, it is intriguing to speculate whether in NET-positive NE tumours, the combination of MIBG and gefitinib might be superior to either drug alone. The mechanisms underlying the observed synergism, however, need further investigation.

To further characterise the antiproliferative action of gefitinib in NE gastrointestinal tumour cells, we studied the cell-cycle phase, at which gefitinib might act. Upon gefitinib treatment, the proportion of cells in the G1/G0 phase significantly increased both in $\mathrm{CM}$ and $\mathrm{BON}$ cells. This suggests that gefitinib acts at the G1/S checkpoint. Cell-cycle arrest by gefitinib at the G1/S checkpoint had previously been described for other tumours, such as head and neck cancer (Huang et al, 2002), malignant pleural mesothelioma (Jänne et al, 2002) and breast cancer (Janmaat et al, 2002). The latter tumour types mainly represent fast-growing cancers known to be very sensitive to growth factors. Many of these cancers produce and release growth factors and thereby autostimulate themselves. This has also been suggested for NE gastrointestinal tumours in which selfproduced transforming growth factor $\alpha(\mathrm{TGF}-\alpha)$ and insulin-like growth factor (IGF) may autostimulate or transactivate EGFR and thereby promote tumour cell growth (Nilsson et al, 1993, 1995). As stromal components of midgut carcinoids also express EGFR, growth factors like TGF- $\alpha$ may similarly contribute to the desmoplastic reaction typical of midgut carcinoids (Öberg, 1994). Thus, EGFR-TK inhibition might as well be a worthwhile strategy to pursue for the control of the desmoplastic reaction and fibrosis of carcinoid disease.

Induction of apoptosis by gefitinib has been reported previously (Ciardiello et al, 2000; Huang et al, 2002; Janmaat et al, 2002). However, the underlying mechanisms are not yet well understood (Mendelsohn, 2002). In this paper, we report on the activation of the proapoptotic enzyme caspase- 3 , which preceded the fragmentation of nuclear DNA into oligonucleosomes. This indicates that in NE tumour cells, gefitinib-mediated apoptosis is caspase-3 dependent. To support our functional data, we additionally performed cancer-specific cDNA arrays, spotted with genes related to proliferation, apoptosis and cell cycle. Treatment with gefitinib resulted in an upregulation of proapoptotic and a suppression of antiapoptotic genes of NE gastrointestinal tumour cells (Table 2). The changes in the expression pattern of the several apoptosisrelated genes were consistent with both our functional data, and reports showing that suppression of antiapoptotic and overexpression of proapoptotic proteins caused programmed cell death (Zamzami et al, 1996). Besides an overexpression of the cell cycle and apoptosis relevant GADD153 gene (see below), a strong upregulation of caspase 4, which has been implicated to play an important role in the execution of apoptosis (Kamada et al, 1997),

\section{REFERENCES}

Ahnert-Hilger G, Stadtbäumer A, Strübing C, Scherübl H, Schultz G, Riecken EO, Wiedenmann B (1996) Gamma-aminobutyric acid secretion from pancreatic neuroendocrine cells. Gastroenterology 110: 1595-1604 was observed. We also observed a strong induction of proapoptotic $B A D$ at the transcriptional level, suggesting a potential involvement of this protein in gefitinib-induced apoptosis. As suggested by others, a dephosphorylation of Akt/PKB by gefitinib may be responsible for the activation of proapoptotic $B A D$ (Albanell et al, 2001). However, further investigations will have to clarify the exact role of $B A D$ in gefitinib-induced apoptosis of NE tumour cells.

Gefitinib's mode of action is known to include the suppression of EGFR-TK-induced activation of MAP kinases, such as ERK1/2 (Albanell et al, 2001; Mendelsohn, 2002). Confirming this notion, gefitinib did cause a time-dependent dephosphorylation and transcriptional downregulation of ERK1/2 in NE tumour cells. In addition, we observed an upregulation of the growth arrest and DNA-damage inducible gene, GADD153, which is involved in G1/ G0 arrest (Wang and Ron, 1996; Oh-Hashi et al, 2001). The expression of GADD153 is known to be regulated by both ERK1/2 and p38 MAPK: While p38 MAPK stimulates the expression of GADD153, ERK1/2 inhibits the expression (Kultz et al, 1998; OhHashi et al, 2001). Interestingly, we did not observe any significant effect of gefitinib on p38 MAPK activity in NE tumour cells. This suggests that the upregulation of GADD153 by gefitinib is mediated by a downregulation of ERK1/2, but not by increased p38 MAPK activity.

Although gefitinib's antiproliferative effect results from the specific inhibition of EGFR-sensitive TK activity, gefitinib's antineoplastic potency not simply reflects the number of EGFRs expressed. While some studies have reported a positive correlation between EGFR expression and gefitinib's antineoplastic action (Meye et al, 2001; Normanno et al, 2002), others have found no such relationship (Ciardiello et al, 2000; Sirotnak et al, 2000). One possible explanation for a missing correlation between EGFR expression and gefitinib's antiproliferative activity may be the presence of constitutively active EGFR mutations, such as EGFRvIII (Moscatello et al, 1995; Wikstrand et al, 1995; Nishikawa et al, 1994). However, in neither NE gastrointestinal tumour model used in this study, an expression of EGFRvIII mutation could be detected and hence could not contribute to the differing effects of gefitinib. Another reason for a missing positive correlation could be EGFR transactivation by other growth factor receptors (Arteaga, 2002). In this respect, Gilmore et al (2002) recently demonstrated a transactivation of EGFR-TK by the IGFR. Gefitinib suppressed the EGFR transactivation by IGFR, and thereby induced apoptosis in breast cancer cells. EGFR transactivation may also be important in NE gastrointestinal tumours in which IGFR is commonly expressed and has been implicated in growth control (Nilsson et al, 1993; Wulbrand et al, 2000).

To conclude, our study provides evidence that the EGFR-TK inhibitor gefitinib induces both cell-cycle arrest and apoptosis in NE gastrointestinal tumour cells. Thus, gefitinib represents a promising novel drug to be tested in patients with metastatic NE gastrointestinal tumour disease.

\section{ACKNOWLEDGEMENTS}

We thank B Ergün for excellent technical assistance. We are indebted to the Institute of Physiology, Free University Berlin, Germany, for laboratory facilities. We also thank AstraZeneca, Great Britain, for providing gefitinib. This study was supported by the grants of the Deutsche Forschungsgemeinschaft.

Albanell J, Codony-Servat J, Rojo F, Del Campo JM, Sauleda S, Anido J, Raspall G, Giralt J, Rosello J, Nicholson RI, Mendelsohn J, Baselga J (2001) Activated extracellular signal-regulated kinases: association with 
epidermal growth factor receptor/transforming growth factor alpha expression in head and neck squamous carcinoma and inhibition by anti-EGF receptor treatments. Cancer Res 61: 6500-6510

Arteaga CL (2002) Epidermal growth factor receptor dependence in human tumors: more than just expression? Oncologist 7: 31-39

Baroni MG, Cavallo MG, Mark M, Monetini L, Stoehrer B, Pozzilli P (1999) Beta-cell gene expression and functional characterisation of the human insulinoma cell line CM. J Endocrinol 161: 59-68

Baselga J (2002) Why the epidermal growth factor receptor? The rationale for cancer therapy. Oncologist 7: 2-8

Baselga J, Rischin D, Ranson M, Calvert H, Raymond E, Kieback DG, Kaye SB, Gianni L, Harris A, Bjork T, Averbuch SD, Feyereislova A, Swaisland A, Rojo F, Albanell J (2002) Phase I safety, pharmacokinetic, and pharmacodynamic trial of ZD1839, a selective oral epidermal growth factor receptor tyrosine kinase inhibitor, in patients with five selected solid tumor types. J Clin Oncol 20: 4292-4302

Brabender J, Danenberg KD, Metzger R, Schnader PM, Park J, Salonga D, Holscher AH, Dannchberg PV (2000) Epidermal growth factor receptor and HER2-neu mRNA expression in non-small cell lung cancer is correlated with survival. Clin Cancer Res 7: 1850-1855

Chan KC, Knox F, Woodburn JR, Slamon DJ, Potten CS, Bundred NJ (2001) Blockade of growth factor receptors in ductal carcinoma in situ of the breast inhibits epithelial proliferation. Br J Surg 88: 412-418

Ciardiello F, Caputo R, Bianco R, Damianco V, Pomatico G, De Placido S, Bianco AR, Tortora G (2000) Antitumor effect and potentiation of cytotoxic drugs activity in human cancer cells by ZD-1839 (ZD1839), an epidermal growth factor receptor-sensitive tyrosine kinase inhibitor. Clin Cancer Res 6: 2053 - 2063

Ciardiello F, Tortora G (2001) A novel approach in the treatment of cancer: targeting the epidermal growth factor receptor. Clin Cancer Res 7: 2958 2970

Cullinane C, Kleinschmidt M, Webster LK (2000) Antitumor activity of ZD1839 (Iressa) in combination with cisplatin in NIH3T3 cells expressing human epidermal growth factor receptor. Proc Am Assoc Cancer Res 41: 537

Di Lorenzo G, Tortora G, D'Armiento FP, De Rosa G, Staibano S, Autorino R, D'Armiento M, De Laurentiis M, De Placido S, Catalano G, Bianco AR, Ciardiello F (2002) Expression of epidermal growth factor receptor correlates with disease relapse and progression to androgen-independence in human prostate cancer. Clin Cancer Res 11: 3438-3444

Ezzat S (2001) The role of hormones, growth factors and their receptors in pituitary tumorigenesis. Brain Pathol 11: 356-370

Faiss S, Scherübl H, Riecken EO, Wiedenmann B (1996) Drug therapy in metastatic neuroendocrine tumors of the gastroenteropancreatic system. Recent Results Cancer Res 142: 193-207

Gilmore AP, Valentijn AJ, Wang P, Ranger AM, Bundred N, O'Hare MJ, Wakeling A, Korsmeyer SJ, Streuli CH (2002) Activation of BAD by therapeutic inhibition of epidermal growth factor receptor and transactivation by insulin-like growth factor receptor. J Biol Chem 277: $27643-27650$

Glassmeier G, Herzig KH, Höpfner M, Lemmer K, Jansen A, Scherübl H (1998) Expression of functional $\mathrm{GABA}_{\mathrm{A}}$ receptors in cholecystokininsecreting gut neuroendocrine murine STC-1 cells. J Physiol (London) 510: $805-814$

Herbst RS (2002) ZD1839: targeting the epidermal growth factor receptor in cancer therapy. Expert Opin Invest Drugs 11: 837-849

Höpfner M, Maaser K, Theiss A, Lenz M, Sutter AP, Riecken EO, Zeitz M, Scherübl H (2003) Apoptotic and antiproliferative effects of photoactivated hypericin on esophageal cancer cells. Int J Colorectal Dis 18: $239-247$

Höpfner M, Maaser K, von Lampe B, Hanski C, Riecken EO, Zeitz M, Scherübl H (2001) Growth inhibition and apoptosis induced by $\mathrm{P}_{2} \mathrm{Y}_{2}$ receptors in human colorectal carcinoma cells: involvement of intracellular calcium and cyclic AMP. Int J Colorectal Dis 16: 154-166

Höpfner M, Sutter AP, Beck N, Barthel B, Maaser K, Zeitz M, Scherübl H (2002) Meta-iodobenzylguanidine induced growth inhibition and apoptosis of neuroendocrine gastrointestinal tumor cells. Int J Cancer 101: $210-216$

Huang SM, Li J, Armstrong EA, Harari PM (2002) Modulation of radiation response and tumor-induced angiogenesis following EGFR inhibition by ZD1839 ('ZD1839'). Cancer Res 62: 4300 - 4306

Janmaat ML, Kruyt FAE, Rodriguez JA, Giaccone G (2002) Inhibition of the epidermal growth factor receptor induces apoptosis in A431 cells but not in non-small-cell lung cancer cell lines. Proc Am Assoc Cancer Res 43: A3901
Jänne PA, Taffaro ML, Salgia R, Johnson BE (2002) Inhibition of epidermal growth factor receptor signaling in malignant pleural mesothelioma. Cancer Res 62: $5242-5247$

Kamada S, Washida M, Hasegawa J, Kusano H, Funahashi Y, Tsujimoto Y (1997) Involvement of caspase-4(-like) protease in Fas-mediated apoptotic pathway. Oncogene 15: 285-290

Kultz D, Madhany S, Burg MB (1998) Hyperosmolality causes growth arrest of murine kidney cells. Induction of GADD45 and GADD153 by osmosensing via stress-activated protein kinase 2. J Biol Chem 273: $13645-13651$

Lemmer K, Ahnert-Hilger G, Höpfner M, Hoegerle S, Faiss S, Grabowski P, Jockers-Scherübl M, Riecken EO, Zeitz M, Scherübl H (2002) Expression of dopamine receptors and transporter in neuroendocrine gastrointestinal tumor cells. Life Sci 71: 667-678

Maaser K, Höpfner M, Jansen A, Weisinger G, Gavish M, Kozikowski AP, Weizman A, Carayon P, Riecken EO, Zeitz M, Scherübl H (2001) Specific ligands of the peripheral benzodiazepine receptor induce apoptosis and cell cycle arrest in human colorectal cancer cells. Br J Cancer 85: 1771 1780

Maaser K, Höpfner M, Kap H, Sutter AP, Barthel B, von Lampe B, Zeitz M, Scherübl H (2002) Extracellular nucleotides inhibit growth of human oesophageal cancer cells via P2Y(2)-receptors. Br J Cancer 86: 636-644

Mendelsohn J (2002) Targeting the epidermal growth factor receptor for cancer therapy. J Clin Oncol 20: 1-13

Mendelsohn J (2003) Antibody mediated EGF receptor blockade as an anticancer therapy: from the laboratory to the clinic. Cancer Immuno Immunother 52: 342-346

Meye A, Fiedler U, Kunert K, Melchior A, Writh D (2001) Growth inhibitory effects of ZD1839 ('Iressa') on human bladder cancer cell lines. Proc Am Assoc Cancer Res 42: 805

Meyers MB, Shen WP, Spengler BA, Ciccarone V, O'Brien JP, Donner DB, Furth ME, Biedler JL (1998) Increased epidermal growth factor receptor in multidrug-resistant human neuroblastoma cells. J Cell Biochem 38: $87-97$

Moghal N, Sternberg PW (1999) Multiple positive and negative regulators of signaling by the EGF-receptor. Curr Opin Cell Biol 11: 190-196

Moscatello DK, Holgado-Madruga M, Godwin AK, Ramirez G, Gunn G, Zoltick PW, Biegel JA, Hayes RL, Wong AJ (1995) Frequent expression of a mutant epidermal growth factor receptor in multiple human tumors. Cancer Res 55: 5536-5539

Nilsson O, Wängberg B, Kölby L, Schultz S, Ahlman H (1995) Expression of transforming growth factor alpha and its receptor in human neuroendocrine tumours. Int J Cancer 60: 645-651

Nilsson O, Wängberg B, McRae A, Dahlström A, Ahlman H (1993) Growth factors and carcinoid tumors. Acta Oncol 32: 115-124

Nishikawa R, Ji XD, Harmon RC, Lazar CS, Gill GN, Cavenee WK, Huang HJ (1994) A mutant epidermal growth factor receptor common in human glioma confers enhanced tumorigenicity. Proc Natl Acad Sci 91: $7727-7731$

Normanno N, Campiglio M, De LA, Somenzi G, Maiello M, Ciardiello F, Gianni L, Salomon DS, Menard S (2002) Cooperative inhibitory effect of ZD1839 (Iressa) in combination with trastuzumab (Herceptin) on human breast cancer cell growth. Ann Oncol 13: 65-72

Öberg K (1994) Expression of growth factors and their receptors in neuroendocrine gut and pancreatic tumors, and prognostic factors for survival. Ann NY Acad Sci 733: 46-55

Öberg K (2001) Chemotherapy and biotherapy in the treatment of neuroendocrine tumors. Ann Oncol 12: S111-S114

Oh-Hashi K, Maruyama W, Isobe K (2001) Peroxynitrite induces GADD34, 45 , and 153 via p38 MAPK in human neuroblastoma SH-SY5Y cells. Free Radical Biol Med 30: 213-221

Overholser JP, Prewett MC, Hooper AT, Waksal HW, Hicklin DJ (2000) Epidermal growth factor receptor blockade by antibody IMC-C225 inhibits growth of a human pancreatic carcinoma xenograft in nude mice. Cancer 89: 74-82

Peghini PL, Iwamoto M, Raffeld M, Chen YJ, Goebel SU, Serrano J, Jensen RT (2002) Overexpression of epidermal growth factor and hepatocyte growth factor receptors in a proportion of gastrinomas correlates with aggressive growth and lower curability. Clin Cancer Res 8: 2273-2285

Ritter CA, Arteaga CL (2003) The epidermal growth factor receptortyrosine kinase: a promising therapeutic target in solid tumors. Semin Oncol 30: 3-11

Sewell JM, Macleod KG, Ritchie A, Smyth JF, Langdon SP (2002) Targeting the EGF receptor in ovarian cancer with the tyrosine kinase inhibitor ZD 1839 ('ZD1839'). Br J Cancer 86: 456-462 
Shimizu T, Tanaka S, Haruma K, Kitadai Y, Yoshihara M, Sumii K, Kajiyama G, Shimamoto F (2000) Growth characteristics of rectal carcinoid tumors. Oncology 59: 229-237

Sirotnak FM, Zakowsky MF, Miller VA, Scher HI, Kris MG (2000) Efficacy of cytotoxic agents against human tumor xenografts is markedly enhanced by coadministration of ZD1839, an inhibitor of EGFR tyrosine kinase. Clin Cancer Res 6: 4885-4892

Sutter AP, Maaser K, Höpfner M, Barthel B, Grabowski P, Faiss S, Carayon P, Zeitz M, Scherübl H (2002) Specific ligands of the peripheral benzodiazepine receptor induce apoptosis and cell cycle arrest in human esophageal cancer cells. Int J Cancer 102: 318-327

Taal BG, Hoefnagel CA, Olmos Valdes RAV, Boot H, Beijnen JH (1996) Palliative effect of meta-iodobenzylguanidine in metastatic carcinoid tumors. J Clin Oncol 14: $1829-1838$

Wang W, Johansson HE, Bergholm UI, Westermark KM, Grimelius LE (1997) Expression of c-Myc, TGF-alpha, EGF-receptor in sporadic medullary thyroid carcinoma. Acta Oncol 36: 407-411

Wang XZ, Ron D (1996) Stress-induced phosphorylation and activation of the transcription factor CHOP (GADD153) by p38 MAP kinase. Science 272: $1347-1349$

Wells A (2000) The epidermal growth factor receptor (EGFR) - a new target in cancer therapy. Signal 1: 4-11
Wikstrand CJ, Hale LP, Batra SK, Hill ML, Humphrey PA, Kurpad SN, McLendon RE, Moscatello D, Pegram CN, Reist CJ, Traweek T, Wong AJ, Zalulsky MR, Bigner DD (1995) Monoclonal antibodies against EGFRvIII are tumor specific and react with breast and lung carcinomas and malignant gliomas. Cancer Res 55: $3140-3148$

Woodburn JR (1999) The epidermal growth factor receptor and its inhibition in cancer therapy. Pharmacol Ther 82: 241-250

Woodburn JR, Morris CQ, Kelly H (1998) EGF receptor tyrosine kinase inhibitors as anti-cancer agents - preclinical and early clinical profile of ZD1839. Cell Mol Biol Lett 3: 348 - 349

Wosikowski K, Schuurhuis D, Kops GJ, Saceda M, Bares SE (1997) Altered gene expression in drug-resistant human breast cancer cells. Clin Cancer Res 3: $2405-2414$

Wulbrand U, Remmert G, Zöfel P, Wied M, Arnold R, Fehmann HC (2000) mRNA expression patterns of insulin-like growth factor components in human neuroendocrine tumors. Eur J Clin Invest 30: 729-739

Wulbrand U, Wied M, Zöfel P, Göke B, Arnold R, Fehmann HC (1998) Growth factor receptor expression in human gastroenteropancreatic neuroendocrine tumours. Eur J Clin Invest 28: 1038-1049

Zamzami N, Susin SA, Marchetti P, Hirsch T, Gomez-Monterrey I, Castedo M, Kroemer G (1996) Mitochondrial control of nuclear apoptosis. J Exp Med 183: $1533-1544$ 